УДК $81-139$

DOI: 10.18101/2305-459X-2019-4-22-27

\title{
ДИСКУРСИВНЫЕ ОСОБЕННОСТИ НАЦИОНАЛЬНОГО ТЕКСТА
}

\author{
(C) Жамсаранова Раиса Гандыбаловна \\ доктор филологических наук, профессор кафедры китайского языка \\ факультета филологии и массовых коммуникаций, \\ Забайкальский государственный университет \\ Россия, 672039, г. Чита, ул. Александрово-Заводская, 30 \\ E-mail: rebeca_zab@mail.ru
}

Статья посвящена проблеме лингвистической интерпретации национального художественного текста «Төөригдэһэн хуби заяан» («Похищенное счастье») известного бурятского прозаика Д. О. Батожабая. В работе затронуты вопросы наличия таких элементов дискурса как тема-рематическая структура (органично связанная с темой (иногда топиком) и связности текста. Дискурсивный анализ позволил обнаружить и доказательно верифицировать наличие имплицитной информации, заключённой в «ткани» текста, посредством определения наличия связности текста как одного из элементов дискурс-анализа. Связность текста лексикализована посредством наличия цепной и параллельной связи предложений в авторском тексте, что способствует пониманию концептуально-когнитивных интенций автора. Таким образом, дискурс национального текста позволяет определить смысловую константу авторского текста, «заключенную» в лингвистике авторского текста.

Ключевые слова: текст, национальный текст, дискурс-анализ, тема-рематическая структура, тема-рематическая структура веерного типа, тема уйдхар «тоска», тема $y h a н$ «вода», цепная и параллельная связности текста.

\section{Для цитирования:}

Жамсаранова Р. Г. Дискурсивные особенности национального текста // Вестник Бурятского государственного университета. Язык. Литература. Культура. 2019. Вып. 4. С. 22-27.

Проблемное поле лингвистической интерпретации текста связано с новейшими направлениями современного языкознания - теорией текста, теорией дискурс-анализа текста, что обусловило методологию изучения художественного текста.

Особый интерес вызывает восприятие текста в лингвистике как «коммуникативной единицы высшего уровня, как цельного речевого произведения» [Валгина, 2003, с. 6]. Под коммуникативностью текста понимается степень обращённости вербального текста к Читателю, своеобразный диалог Автора и Читателя. В этой связке третьей стороной выступает и сам Текст, как субъект условной триады, обладающий какими-то своими функционально-прагматическими, эстетическими, коммуникативными и прочими возможностями в процессе коммуницирования Автор-Текст-Читатель.

Текст как таковой не состоит из нескольких предложений или одного предложения, абзацев, отрывков, глав. Эти составные элементы только реализуют текст, вернее, его смысловое содержание. В литературоведении принято называть это авторским замыслом. В связи с этим закономерен вопрос - каким образом авторский замысел как смысл «коммуникативного» посыла потенциальному 
Читателю может стать доступным и очевидным последнему? И, по-видимому, в этой проекции важно выяснить функции именно текста, т. к. общение автора с читателем и происходит, и возможно только посредством текста.

Ведь термин текст понимается как некое сплетение интенций, посылов, авторских задумок и помыслов в некую «ткань» или соединение фактов, событий, инцидентов, событий, имён и персоналий. В этом смысле текст представляет собой «объединённую по смыслу последовательность знаковых единиц, основными свойствами которой являются связанность и цельность» [Валгиина, 2003, c. 9].

Последовательно связанные между собой, как бы «сцепленные» знаковые единицы, вербализованные разными языковыми единицами, создают в итоге цельное литературное произведение или художественный текст. Эта последовательность «сплетённых» между собою дополнительными внутренними связями (или «сцепками») представляет собой, по мнению Н. С. Валгиной, «коммуникативную единицу высшего уровня, поскольку она обладает качеством смысловой завершённости как цельного литературного произведения, т. е. законченное информационное и структурное целое» [Валгина, 2003, с. 9].

Наиболее отчётливо обнаруживается коммуникативная природа текста при изучении его с позиций дискурс-анализа художественного текста. Причем «текст и дискурс существуют в совокупности в рамках реального речевого произведения» [Наep, 2006, с. 7-15].

Другими словами, «интерпретируя вербальные структуры, образующие текст, мы получаем доступ к концептуальным и эмоциональным сферам дискурса» [см. Наер, 2006, с. 7-15], что позволяет лингвисту выявить и описать интенциональный аспект авторского текста посредством дискурса или дискурсанализа художественного текста. В дискурсе отчётливо проявляется личность адресанта, его позиции, эмоции, оценки, намерения. В тексте эти параметры вербализуются. Дискурс ориентирован на концептуальную сферу речевой деятельности, в то время как текст - на вербальную» [Сердюк, 2012, с. 75].

Добавим, что именно коммуникативность текста «заключает» когнитивноэмоциональную сферу замысла Автора в виде некоего смыслового посыла Читателю посредством самого же Текста.

Дискурс многомерен, многоаспектен, состоит из многих элементов. Различают макро- и микроструктуры дискурса. Ключевыми элементами являются тема и рема. При этом тему как основную смысловую константу текстового произведения возможно определить посредством дискурс-анализа.

Для иллюстрации обратимся к тексту романа бурятского писателя Д. О. Батожабая «Похищенное счастье» («Төөригдэһэн хуби заяан»).

Чувства, которые испытывает главный герой романа Аламжи по отношению и к покинутой родине, и к покинутой семье, описаны Д. О. Батожабаем настолько реалистично, настолько эмоционально и художественно, что невольно возникает вопрос о том, каков же набор тех лингвистических авторских средств, посредством которых Батожабаю удаётся создать такой текст, который по степени своего воздействия на читающего позволяет заслуженно считать его выдающимся бурятским классиком-прозаиком [Жамсаранова, 2018, с. 92-94].

Остановимся на таком элементе как наличие связности текста. Известно, что одна из главных составляющих дискурс-анализа - связность текста - проявля- 
ется в том, что каждое последующее предложение возникает на основе смысла предыдущего, вбирая при этом в себя ту или иную его часть. Принято именовать ту информацию, которая повторяется в последующем предложении из предыдущего, как «данное», а то, что сообщается дополнительно, - «новое», которое выделяется логическим ударением и стоит в конце предложения. Роль «нового» - в развитии мысли в тексте, роль «данного» заключается в связи предложений между собой.

Для связи предложений в тексте, «данного» и «нового», используются два способа связи: цепная связь и параллельная связь. Эти типы связности текста в парадигме дискурс-анализа способны выявить интенции авторского замысла, подругому, ту информацию, которую в теории дискурса понимают как тема.

Так, при дискурс-анализе текста романа Төөригдэһэн хуби заяан («Похищенное счастье») выявлено, что тема тоска передаётся словами уйдхар и гуниг, имеющие значение «печаль, грусть, тоска, уныние» [Бурятско-русский словарь, 1973, с. 160]. При этом автор использует в качестве синонимов ключевого слова тоска - уйдхар и такие слова как гуниг, гашуудал - «печаль, грусть, скорбь, тоска, уныние», что позволяет определить организацию текста как цепную посредством синонимических повторов основной темы. Для героя романа Аламжи тоска по Родине, семье и любовная тоска тесно переплелись, выражают единое чувство уже безысходной печали (уже не грусти, и не тоски), впечатляя читателя. Автору романа удалось передать всю невысказанную боль разлучённой жизнью молодой пары посредством подбора не только синонимов слова тоска, символизирующей бренный путь Аламжи, а также слов сэдьхэл «душа» и үбшэн «боль» т. е. тоска - это не грусть, не скорбь, не уныние и даже не печаль, а душевная боль, раздирающая сердце Аламжи. Читатель, в свою очередь, воспринимает текст наиболее ярко и глубоко за счёт построения тема-рематической связности текста в отдельных сюжетных линиях как верифицированный аспект темы тоска [Жамсаранова, 2018, с. 94].

Помимо цепной связи предложений (о тоске героя) в тексте романа, где тема тоска выражена синонимами, наблюдается наличие и параллельной связи, когда предложения не зависят непосредственно друг от друга, но обычно построены вокруг какого-нибудь центрального тезиса или образа. Каждое из них выглядит самостоятельным по содержанию, но при этом является частью какого-то общего перечня, сопоставления или противопоставления. Примером служат предложения, смысл которых объединён одной темой, темой водыl. «Эндэ һаяхан нарин зурамаар урдажа байһан хадын хунды дүүрэн уһатай боложо байна. Хадаһаa урдаһан уһан хэдыхэн сагсоо уерлэжэ, аяншадай амархаа тогтоһон газар уһанда абтахаа байна» [Батожабай, 1966, с. 158] / Ущелье, на дне которого ещё недавно чуть заметной ленточкой пробегал ручек, теперь наполнялось водой. Горный поток с каждой минутой подступал к площадке, где путники с лошадьми остановились на отдых [Похищенное счастье, 1967]. «Уры бухы дайда дүүргэжэ, харьялан урдажа байна. Уһан гансаш дээрэһээ бэшэ, харин хадын боориһоо урдажа, бухы дайдын модо шулуу угаажа, ундэһэтэй модонууд урдаа» / (Вода стремительно разливалась во все стороны. Вода прибывала не только из верховий. Она низвергалась с горных склонов, увлекая за собой камни; обгоняя друг друга, плыли вырванные с корнем деревья). «Эндэ һаяхан нарин зурамаар урдажа байһан хадын хунды дүүрэн уһатай боложо байна. Хадаһаa урдаһан уһан хэдыхэн сагсоо 
уерлэжэ, аяншадай амархаа тогтоһон газар уһанда абтахаа байна» / «Вода стремительно разливалась во все стороны. Вода прибывала не только из верховий. Она низвергалась с горных склонов, увлекая за собой камни; обгоняя друг друга, плыли вырванные с корнем деревья». «Ехэ уһан дутэлэжэл байба, хадын шулуун хэмхэржэ, бурьялан ехэ урыруу унана, мургэлдэжэ урдана. Аяншадай байхан газарта ойро ерьюулгэ болошобо» / «Вода становилась все яростнее, камни со скал падали в водоворот, сталкиваясь и разбиваясь друг об друга в этом водовороте, который возник в один миг на равнинном месте. «Уһан уры ехэдэнэ, эрьюлгэдэ нэгэ модон абтажа, саашаа урдаба. Уһан гарахаа болижо, шулуунай захаар шулуун, модон эльхэн тогтожо, ундыбэ. Уһанай догин энэ юумэ суглуулжа, энээндээ дараа, саашаа урдана» / «Вода становилась все яростнее. В водоворот попало ещё одно дерево. Деревья еще некоторое время колыхались возле площадки, затем, подхваченные новым потоком, понеслись вниз». «Между тем, вода быстро ушла на убыль. Стихия улеглась также быстро, как и взъярилась» [Батожабай, 1966, c. 158].

Тема воды раскрывает смысл внутреннего состояния героя романа, когда описание всей силы и мощи водной стихии сродни тем ощущениям, которые испытывает герой в душе. Ключевое слово вода, многократно повторяясь, связывает воедино весь фрагмент текста, состоящий из межфразовых единств: вода стремительно разливалась во все сторонь; вода подступала все ближе; вода становилась все яростнее; между тем, вода быстро ушла на убыль.

Известно, что в дискурс-анализе такой элемент как тема-рематическая структура текста играет одну из ключевых ролей как при создании текста, так и при её восприятии и интерпретации читателем. На этом примере можно определить наличие тема-рематической структуры веерного типа с повторяющейся стабильной темой и разными ремами. Рема «добавляет» новую информацию, расширяя тему. По сути, это развёртывание одной темы, темы вода, которая помогает передать другой, глубинный смысл сюжета: физическое и душевное состояние «наблюдателей». Думается, что таким образом автору удалось через ключевые слова создать не только сюжетный фон произведения, но и нечто большее, а именно, передать глубинный смысл национального текста. Известно, что в национальной картине мира вода как языковой знак символизирует не только очищение от скверны, но и умиротворённость. В тексте тема вода символизирует жизненный путь героя, происходящие в его душе потрясения и изменения, вызванные несправедливостью жизни или, по-другому, судьбы. Авторский замысел о счастливой судьбе человека, которая реализуется не в этой жизни, не у этого главного героя Аламжи, а у другого, например, у его сына Булада, заключён в символизме умиротворённости бытия, текущей далее как вода.

Роман-трилогия «Төөригдэһэн хуби заяан» — это «первая национальная историческая эпопея, отразившая переломный кризисный момент национальной истории, когда в полной мере раскрывается национальное самосознание, «дух народа» [Серебрякова, 2013, с. 25]. Смысл произведения «Төөригдэһэн хуби заяан», точнее, один из смыслов - революционный переворот в самосознании простого бурята под влиянием социально-политических событий эпохи, куда как в водоворот втянуты все - и люди, и животные, и природа.

Ключевые слова, становясь доминантными обозначениями, создают вокруг себя единый смысловой контекст, вовлекая в него другие слова, ситуативно свя- 
занные со словом - понятием, избранным в качестве ключевого. Ключевые слова создают семантические текстовые поля и как важный элемент текста, могут оказаться центральными в системе образов того или иного автора произведения. Ключевое слово или тема, вербализованная лексемным уhан дополняется ремой Хадаһаa урдаһан уһан / <вода> низвергалась с горных склонов; хадын хунды дүүрэн уһатай / <горное ущелье> теперь наполнялось водой; уерлэжэ / <вода> стремительно разливалась во все стороны; Ехэ уһан / большая вода (досл.); ойро ерьюулгэ / водоворот, который возник в один миг на равнинном месте; Уһан уры ехэдэнэ / Вода становилась все яростнее; Уһан гарахаа болижо / вода быстро ушла на убыль; Уһанай догин энэ юумэ суглуулжа / Стихия улеглась также быстро, как и взъярилась.

Таким образом, лингвистическая интерпретация художественного национального текста как с позиций теории текста, так и теории дискурса способна предоставить филологу более глубокое осмысление произведения эпического плана, каковым по праву является роман-трилогия Д. О. Батожабая. Лингвистика текста, реализованная в авторском национальном тексте, позволяет определить неочевидные авторские интенции, относящиеся к области авторской концептосферы, обнаруживая «личность адресанта, его позиции, эмоции, оценки, намерения». С другой стороны, Читатель как и сам Автор находит отклик своим душевным нравственным исканиям в Тексте и как системе языковых знаков, и как «коммуникативной единице высшего уровня».

Литература

1. Батожабай Д. О. Төөригдэһэн хуби заяан. Улан-Удэ: Буряадай номой хэблэл, 1966. $360 \mathrm{c}$.

2. Бурятско-русский словарь. Буряад-ород словарь / сост. К. М. Черемисов. М.: Советская энциклопедия, 1973. $803 \mathrm{c.}$

3. Валгина Н. С. Теория текста: учеб. пос. М.: Логос, 2003. 280 с.

4. Жамсаранова Р. Г., Цыренова Н. Н. Тема-рематическая организация темы тоска в романе Д. О. Батожабая «Похищенное счастье» // Лингвистика и межкультурная коммуникация: материалы всерос. науч.-практ. конф. / отв. ред. Т. В. Воронченко. 2018. C. 92-94. C. $7-15$.

5. Наер В. Л. Дискурс и речь: речевое произведение: сб. науч. тр. / МГЛУ. М., 2006.

6. Батожабай Д. О. Похищенное счастье: роман: в 3 т. / пер. с бурят. Н. Рыбко. УланУдэ: Бурят. кн. изд-во, 1967.

7. Сердюк Е. Н. К проблеме определения признаков художественного дискурса // Культура народов Причерноморья. 2012. № 226. С. 85-87 [Электронный ресурс] // URL: http://dspace.nbuv.gov.ua/bitstream/handle/123456789/56015/25-Serdiuk.pdf (дата обращения: 15.11.2017).

8. Серебрякова 3. А. Национальный характер в романе Д. Батожабая «Похищенное счастье» [Электронный ресурс] // Вестник Бурятского государственного университета, 2013. Вып. 10. . 24-28. URL: https://socionet.ru/d/spz:cyberleninka:29176:14554253/ http://cyberleninka.ru/article/n/natsionalnyy-harakter-v-romane-d-batozhabaya-pohischennoeschastie (дата обращения: 20.10.2018). 


\section{PECULIARITIES OF THE DISCOURSE ANALYSIS OF THE NATIONAL TEXT}

\section{(C) Raisa G. Zhamsaranova}

Doctor of Sciences in Philology, professor of the department of Chinese language of the Faculty of Philology and Mass Communications of Transbaikal State University

30, Alexandrovo-Zavodskaya Str., Chita, 672039 Russia

E-mail: rebeca_zab@mail.ru

The article is devoted to the problem of linguistic interpretation of the national text "The stolen happiness” D.O. Batozhabai. The problem of the linguistic interpretation of the text is associated with the latest trends of modern linguistics - the theory of text, the theory of discourse analysis of the text, which led to the methodology of the study of literary text. The article touches upon the questions of the existence of such elements of discourse as theme-rheme structure (organically linked with the subject (sometimes topic)) and coherence of the text. It is known that discourse allows the researcher to detect and evidently verify the presence of implicit information contained in the"fabric" of the text by determining the presence of coherenceof the text as one of the elements of discourse analysis. The coherence of the text is lexicalized by the presence of means of a chain and parallel connection of sentences in the author's text. The definition of the coherence of the text contributes to the understanding of the conceptual and cognitive intentions of the author. The definition of the coherenceof text contributes to the understanding of conceptual and cognitive intentions of the author. Thus, the discourse of the national text makes it possible to determine the semantic constant of the author's text, "enclosed" in the linguistics of the author's text.

Keywords: text, national text, discourse analysis, the theme and rheme construction, the theme and rheme construction of radial type, theme, theme уйдхар «melancholy», theme yhat «water», chain and parallel coherence of the text. 